\title{
IMPLEMENTASI ALGORITMA APRIORI DAN FORWARD CHAINING UNTUK MENENTUKAN MAKANAN YANG TEPAT PADA PENDERITA DIABETES
}

\author{
Agatha Deolika ${ }^{1}$, Victor Saputra Ginting ${ }^{2}$, Tutik Maryana ${ }^{3}$, Ripto Sudiyarno ${ }^{4}, \mathrm{Kusrini}^{5}$ \\ Magister Teknik Informatika, Universitas Amikom Yogyakarta \\ Jl. Ring Road Utara, Kabupaten Sleman, Daerah Istimewa Yogyakarta \\ Email: 1agatha.deolika@students.amikom.ac.id, ${ }^{2}$ victor.ginting@students.amikom.ac.id, \\ 3tutik.maryana@ students.amikom.ac.id, ${ }^{4}$ ripto.s@ students.amikom.ac.id, ${ }^{5}$ kusrini@ amikom.ac.id

\begin{abstract}
The high number of diabetes patients in Indonesia is increasing. Some of the factors that cause diabetes in Indonesia include family history, obesity, aging, lack of activity and diet. Too much food containing sugar is also one of the emergences of diabetes. Most diabetics often have complications of diabetes disease and that is based on the criteria of a patient. Therefore, it is necessary to conduct research on the rule or dependence of the disease based on patient criteria and determination of diet for diabetics. In this study using a combination of a priori methods to determine the rule of disease and forward chaining to determine patient food. Based on the research tests conducted, it can be concluded that the combination of 2 methods produces a pretty good which in the a priori method uses a minimum value of support 2 and a minimum of confidence 10 and produces 10 rules with 3 combinations of items, as well as forward chaining tests that use 30 data produces an accuracy of $83 \%$.
\end{abstract}

Keywords - Apriori Algorithm, Forward Chaining, Diabetes

Abstrak - Tingginya jumlah pasien diabetes yang terjadi di Indonesia semakin meningkat. Beberapa faktor penyebab penyakit diabetes di Indonesia anatara lain riwayat keluarga, obesitas, pertambahan usia, kurangnya aktivitas dan pola makan. Terlalu banyak makan yang mengandung gula juga merupakan salah satu munculnya penyakit diabetes. Kebanyakan penderita diabetes sering sekali terjadinya kompliksi penyait diabetes dan itu berdasarkan kreteria seorang pasien. Maka dari itu perlu dilakukan penelitian mengenai rule atau keterhungungan penyakit berdasarkan kriteria pasien dan penentuan pola makan bagi penderita penyakit diabetes. Pada penelitian ini menggunakan kombinasi metode apriori untuk menetukan rule penyakit dan forward chainning untuk mentukan makanan pasien. Berdasarkan pada pengujian penelitian yang dilakukan dapat diambil kesimpulan Kombinasi 2 metode ini menghasilkan cukup bagus yang mana pada metode apriori menggunakan nilai minimal support 2 dan minimal confidence 10 dan menghasilkan 10 rule dengan 3 kombinasi item, serta pengujian forward chaining yang menggunakan 30 data menghasilkan akurasi $83 \%$.

Kata Kunci - Algoritma Apriori, Forward Chaining, Diabetes

\section{PENDAHULUAN}

Diabetes adalah penyakit dengan keadaan kadar gula glikosa (gula sederhana) pada darah berada pada keadaan tinggi sehingga tubuh manusia tidak dapat melepaskan atau menggunakan insulin secara cukup. Insulin merupakan hormon yang diperlukan untuk mengkonversi gula, zat tepung, dan makanan lain ke dalam bentuk energi yang diperlukan untuk aktivitas sehari- hari. Penyebab diabetes berlanjut ke suatu misteri, meskipun faktor genetik dan gaya hidup misal obesitas dan kurangnya olahraga ikut berperan. Sesuai dengan studi jumlah penderita diabetes di bebagai negara di dunia, Indonesia menduduki posisi empat teratas yaitu dengan jumlah kurang lebih 8,4 juta pada tahun 2020. Studi populasi yang dilakukan Organisasi Kesehatan Dunia (WHO) tahun itu menyebutkan, Indonesia berada di posisi keempat di bawah India (31,7 juta orang), Cina (20,8 juta orang), dan AS (17,7 juta orang). Diperkirakan, prevalensi diabetes akan terus meningkat bersamaan dengan perubahan gaya hidup dan pola konsumsi makanan agar dapat mengontrol tekanan darah. Penyakit diabetes kadang-kadang berhubungan atau komplikasi dengan penyakit lain maka dari itu sangat diperlukan system yang dapat menghasilkan rule-rule berdasarkan kreteria pasien. Maka dari itu pada penelitian ini menggunakan metode apriori untuk mementukan rule penyakit diabetes berdasarkan kriterian dari pasien. Penelitian lainnya mengatakan algoritma Apriori salah satu bentuk terapan data mining yang menghasilkan model pengetahuan berupa aturan dengan nilai confidence. Model pengetahuan tersebut dapat digunakan untuk memprediksi kecenderungan data yang akan datang[1]. Salah satu alternatif sebagai solusi dari masalah tersebut adalah membuat suatu pencarian pola atau hubungan Association rule (aturan asosiatif) dari data yang berskala besar dan kaitannya sangat erat dengan data mining yang dapat digunakan untuk menemukan aturan-aturan tertentu yang mengasosiasikan data yang satu dengan data yang lainnya dengan Metode algoritma apriori bisa melakukan penelusuran pada data historis untuk mengidentifikasi pola data yang didasarkan pada sifat-sifat yang teridentifikasi sebelumnya[2].

Makanan pasien diabetes sangat perlu diperhatikan karena pasien diabetes kadar gulanya tidak boleh berlebihan maka dari itu perlu adanya system pengambilan keputusan pasien diabetes untuk 
pemilihan makanan yang sesuai dengan kriterian pasien. Dalam penelititian ini menggunakan metode Forward Chaining dalam mendukung efektifitas kinerja sistem pendukung keputusan yang dibangun, dimana metode Forward Chaining banyak di gunakan dalam menentukan permasalahan yang di hadapai dalam penentuan pemilihan[3]. Berdasarkan analisis, sistem pakar ini memiliki prosentase kelayakan program untuk digunakan oleh orang awam adalah sebesar $85.4 \%$. Selain itu berdasarkan hasil kuisioner, kemudahan program ini juga mendapatkan prosentase yang besar juga[4].

Berdasarkan penelitian yang sudah dijelaskan diatas maka pada penelitian ini penulis tertarik melakukan eksperimen menggabungkan atau mengkombinasikan 2 metode yaitu algoritma apriori dan metode forward chaining untuk menentukan pola makan yang tepat untuk penderita diabetes dengan melihat variabel-variabel yang ada didalam nya, seperti indek Glikemik, Beban Glikemik, Riwayat Penyakit.

\section{A. Pengertian Makanan Sehat Menurut Beberapa Ahli}

Makanan sehat adalah dengan meramu berbagai jenis makanan yang seimbang, sehingga terpenuhi seluruh kebutuhan gizi bagi tubuh dan mampu dirasakan secara fisik dan mental[5].

\section{B. Pengaruh Makanan Untuk Penderita Diabetes}

Setiap manusia pasti ingin sehat dan prima sehingga dapat memiliki usia produktif yang panjang. Salah satu upaya yang dapat dilakukan untuk mempertahankan kesehatan adalah dengan cara mengatur pola makan sesuai dengan kondisi tubuh. Kebutuhan gizi setiap orang akan berbeda sesuai dengan usia, jenis kelamin, jenis pekerjaan dan kondisi fisiologi (hamil, menyusui atau mengidap penyakit tertentu). Pengetahuan tentang hal tersebut sangat penting sehingga dalam memilih makanan dan jumlah yang dikonsumsi sesuai kebutuhan dan karakteristik kondisi tubuh. Penderita diabetes mellitus (diabetesi) membutuhkan makanan yang berbeda dengan orang normal atau orang yang menderita penyakit lain. Selain mengonsumsi obat, makanan pun sangat berperan dalam membantu proses penyembuhan maupun menjaga kestabilan kondisi kesehatan seseorang. Makanan dapat membantu memulihkan kesehatan melalui berbagai manfaat kandungan zat gizi yang dimilikinya[6]. Makanan dan minuman sangat erat hubungannya dengan Diabetes Mellitus. Kelebihan makanan dan minuman yang banyak mengandung gula dan protein akan menyebabkan obesitas (kegemukan). Obesitas merupakan faktor resiko terjadinya diabetes mellitus. Pada kondisi kelebihan nutrisi, insulin akan bekerja terus untuk memecah gula menjadi energi. Jika kelebihan nutrisi berlangsung lama akan memperburuk kerja pankreas. Jumlah penderita Diabetes Mellitus akibat kelebihan makanan semakin hari semakin bertambah.

\section{Syarat Makanan Sehat Bagi Penderita Diabetes}

Dalam memilih makanan untuk dikonsumsi, penderita diabetes harus memperhatikan jenis karbohidrat yang terkandung dalam makanan tersebut. Ada jenis karbohidrat yang cepat diserap tubuh (sehingga kadar gula darah melonjak dan cepat terasa lapar lagi), ada juga karbohidrat yang lambat diserap (sehingga kadar glukosa darah lebih stabil dan terasa kenyang lebih lama).

\section{Sistem Pendukung Keputusan}

Sistem pendukung keputusan (SPK) yang dikenal dengan Decission Support Systems (DSS) merupakan kelanjutan dari pengembangan Management Information System (MIS) yang dirancang sedemikian rupa sehingga bersifat lebih interaktif dengan pemakainya. Secara teori sistem pendukung keputusan adalah suatu kumpulan model dasar yang didasari prosedur-prosedur dalam pengolahan data dan penilaian untuk membantu manajer membuat suatu keputusanakan lebih mudah diselesaikan.

\section{E. Metode Forward Chaining}

Forward chaining adalah salah satu metode dari sistem pakar yang mencari atau menelusuri solusi melalui masalah[7]. Dengan kata lain metode ini melakukan pertimbangan dari fakta- fakta yang kemudian berujung pada sebuah kesimpulan yang berdasarkan pada fakta-fakta. Metode ini merupakan kebalikan dari metode backward chaining yang melakukan pencarian yang berawal dari hipotesis menuju ke fakta- fakta untuk mendukung hipotesis tersebut. Pada metode forward chaining, penjelasan tidak terlalu terlalu terfasilitasi karena subgoals tidak diketahui secara eksplisit sebelum kesimpulannya ditemukan. Forward chaining disebut juga bottom-up reasoning atau pertimbangan dari bawah ke atas, karena metode ini mempertimbangkan dari bukti-bukti pada level bawah, faktafakta, menuju ke kesimpulan pada level atas yang berdasarkan pada fakta-fakta.

\section{F. Konsep Aturan Asosiasi (Association Rule)}

Analisis asosiasi atau association rule mining adalah merupakan teknik data mining yang digunakan untuk menemukan pola yang menggambarkan kekuatan hubungan fitur dalam data. Pola yang ditemukan biasanya merepresentasikan bentuk aturan implikasi atau subset fitur. Tujuannya adalah 
menemukan pola yang menarik dengan cara yang efisien[8].

Association rules mining adalah suatu prosedur untuk mencari hubungan antar item suatu dataset yang telah ditentukan. Association rules mining mencari dan menemukan hubungan antar item yang ada pada suatu dataset. Penerapan data mining dengan aturan asosiasi bertujuan menemukan informasi item-item yang saling berhubungan dalam bentuk aturan/rule. Aturan asosiasi adalah teknik data mining untuk menemukan aturan asosiasi antara suatu kombinasi item[9].

\section{G. Algoritma Apriori}

Algoritma apriori adalah suatu algoritma dasar yang diusulkan oleh Agrawal \& Srikant pada tahun 1994 untuk menentukan Frequent itemsets untuk aturan asosiasi Boolean. Algoritma Apriori termasuk jenis Aturan Asosiasi pada data mining. Aturan yang menyatakan asosiasi antara beberapa atribut sering disebut affinity analysis atau market basket analysis. Analisis asosiasi atau association rule mining adalah teknik data mining untuk menemukan aturan suatu kombinasi item. Salah satu tahap analisis asosiasi yang menarik perhatian banyak peneliti untuk menghasilkan algoritma yang efisien adalah analisis pola frequensi tinggi(frequent pattern mining). Penting tidaknya suatu asosiasi dapat diketahui dengan dua tolok ukur, yaitu : support dan confidence. Support (nilai penunjang) adalah persentase kombinasi item tersebut dalam database, sedangkan confidence (nilai kepastian) adalah kuatnya hubungan antara-item dalam aturan asosiasi[10].

\section{METODE PENELITIAN}

Penelitian yang akan diusulkan berjenis eksperimen, yang mana penelitian ini bertujuan menganalisis kombinasi metode pada penyakit diabetes. Penelitian ini menggunakan pendekatan kuantitatif berupa data pasien dan kriteria pasien. Dalam penelitian ini metode penelitian dilakukan dengan menguji metode algoritma apriori dan forward chaining untuk menentukan makanan yang tepat untuk penderita diabetes.

Metode pengumpulan data yang lakukan adalah dengan cara menggunakan data pada penelitian sebelumnya yang berjudul "sistem pendukung keputusan pemilihan makanan sehat penderita diabetes mellitus menggunakan metode forward chaining" yang akan dibuat menjadi dataset.

Alur penelitian yang akan dilakukan dapat dilihat pada gambar 1 yaitu sebagai berikut:

1. Identifikasi masalah

Dalam proses identifikasi masalah pemilihan dan perumusan masalah serta identifikasi definisi operasional dari masalah yang dihadapi.
2. Tinjauan literatur

Barisi bagaimana mencari sumber data, contoh data, penentuan object penelitian dan jenis dataset yang digunakan.

3. Penentuan algoritma/metode Pemilihan algoritma yang relevan atau terkait dengan penelitian terdapat pada tahap ini.

4. Pengumpulan data

Ketika algoritma sudah didapatkan maka selanjutnya bagaimana mengumpulkan data baik dari jenis dataset, jumlah dataset dan variasi dataset yang diperlukan.

5. Pengolahan data

Dalam pengolahan data akan dibagi 2 yaitu data untuk apriori dan data untuk forward chaining seperti data diognosa pasien untuk apriori dan data keinginan/ pilihan makanan untuk forward chaining

6. Proses algoritma

Proses algoritma pada penelitian ini terbagi menjadi 2 yaitu:

\section{a. Apriori}

Proses apriori pada penelitian ini untuk menentukan kombinasi penyakit diabetes berdasarkan dari diagnosa dan profil pasien.

b. Forward Chaining

Pada proses ini menggunakan data rule berdasarkan hasil dari proses Apriori dan data yang di gunakan data keinginan pasen untuk menentukan pilihan/keinginan pasien ingin makan jenis makanan sepeti apa.

7. Kesimpulan dan evaluasi

Dalam kesimpulan akan di uji berdasakan data manual dan data hasil system dari penelitian yang telah dilakukan.

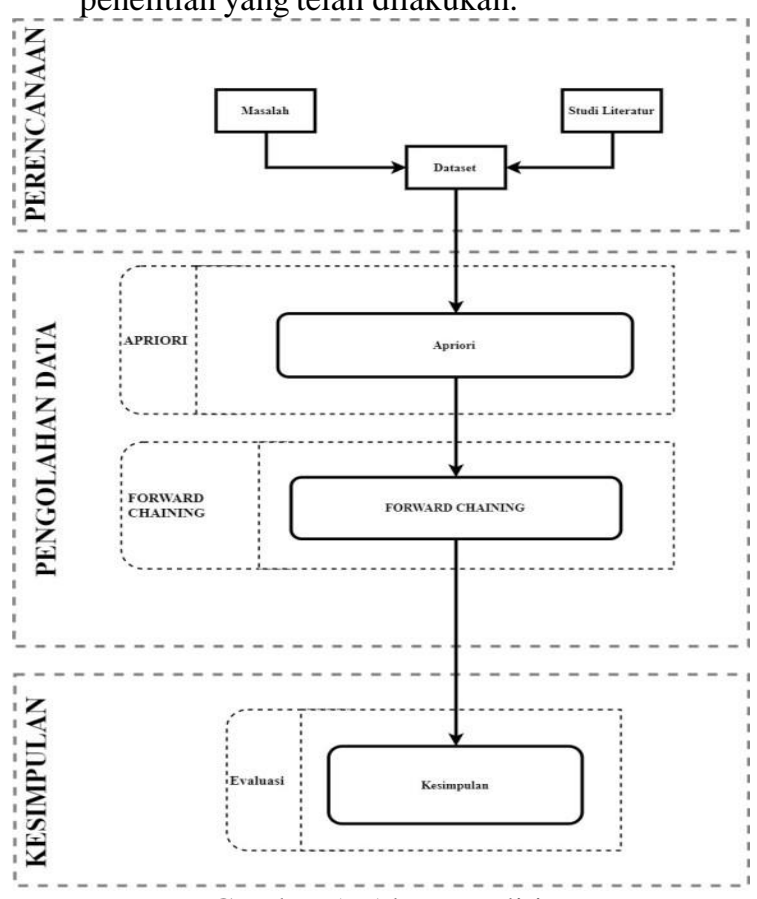

Gambar 1. Alur Penelitian 


\section{HASIL DAN PEMBAHASAN}

Dataset untuk pengujian algoritma apriori dapat dilihat pada Table 1, sebagai berikut:

Tabel 1. Tabel Set Rule Apriori

\begin{tabular}{|c|l|}
\hline No & \multicolumn{1}{|c|}{ Item } \\
\hline 1 & $\begin{array}{l}\text { ASAM URAT, PARU- } \\
\text { PARU,JANTUNG,UMUR 17 }\end{array}$ \\
\hline 2 & JANTUNG,DIABETES,UMUR 18 \\
\hline 3 & $\begin{array}{l}\text { DIABETES,JANTUNG,ASAM } \\
\text { URAT,STROKE,UMUR 19 }\end{array}$ \\
\hline 4 & $\begin{array}{l}\text { DIABETES,JANTUNG,ASAM } \\
\text { URAT,PARU-PARU,UMUR 19 }\end{array}$ \\
\hline 5 & PARU-PARU,ASAM URAT,UMUR 17 \\
\hline 6 & $\begin{array}{l}\text { DIABETES,PARU- } \\
\text { PARU,JANTUNG,STROKE,UMUR 17 }\end{array}$ \\
\hline 7 & $\begin{array}{l}\text { DIABETES,STROKE,ASAM } \\
\text { URAT,DIABETES,UMUR 18 }\end{array}$ \\
\hline
\end{tabular}

Dilakukan proses algoritma apriori menggunakan nilai min support 2 dan min confidence 10 , menghasilkan 10 data rule dengan 3 kombinasi item yang dapat dilihat pada Gambar 2

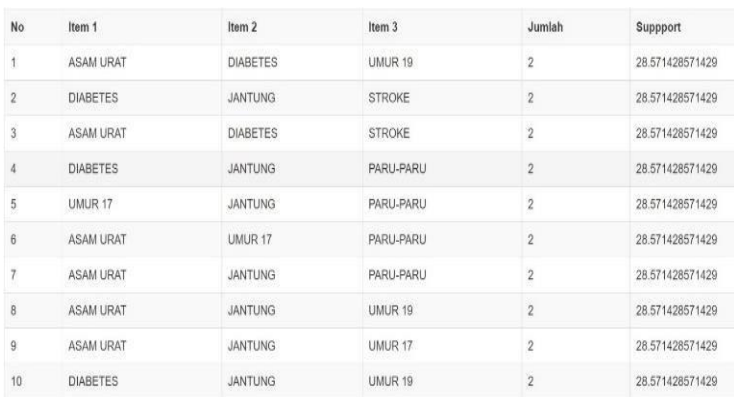

Gambar 2. Hasil Rule Apriori 3 Set

Dari hasil 3 kombinasi tersebut akan digunakan menjadi rule proses forward chaining untuk menentukan makanan yang cocok untuk pasien dapat dilihat pada Gambar 3

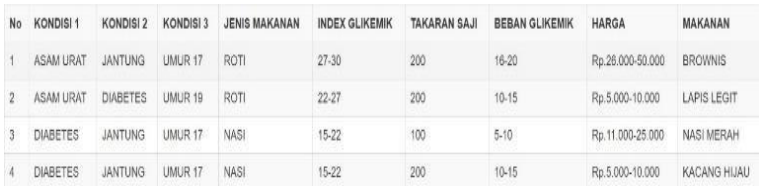

Gambar 3. Hasil Pengujian Forward Chaining

Berdasarkan rule yang dihasilkan dari Gambar 3 maka dilakukan pengujian dengan 30 data, menghasilkan 25 data yang menunjukan akurat berdasarkan dari pakar pada Tabel 2 .
Tabel 2. Tabel Pengujian

\begin{tabular}{|l|l|l|}
\hline Data N & Sistem & Pakar \\
\hline Data 1 & Brownis & Brownis \\
\hline Data 2 & Nasi Merah & Nasi Merah \\
\hline Data 3 & Lapis Legit & Brownis \\
\hline$\ldots$ & \multicolumn{2}{|l|}{} \\
\hline Data 30 & $\begin{array}{l}\text { Kacang } \\
\text { Hijau }\end{array}$ & $\begin{array}{l}\text { Kacang } \\
\text { Hijau }\end{array}$ \\
\hline
\end{tabular}

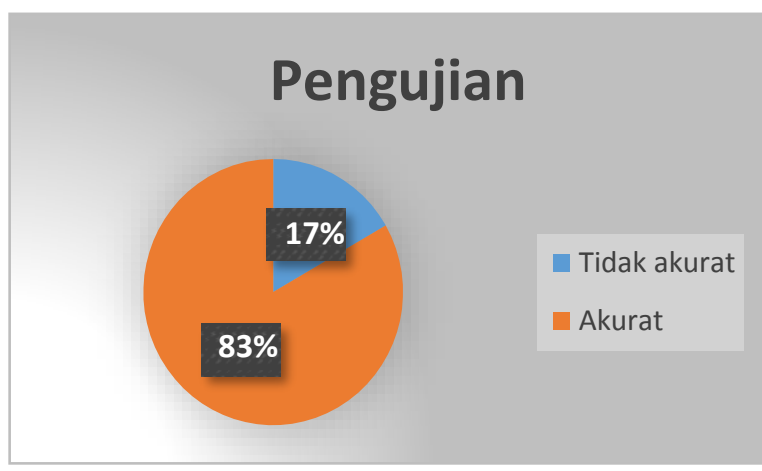

Gambar 4. Grafik pengujian

\section{KESIMPULAN}

Berdasarkan dari pengujian 2 kombinasi metode apriori dan forward chaining mendapatkan hasil yang cukup memuaskan. Pada metode apriori mendapatkan 10 data rule yang terdiri dari 3 kombinasi item dengan min support 2 dan min confidence 10. Serta pada metode forward chaining menghasilkan akurasi $83 \%$ dari 30 dataset.

\section{SARAN}

Berdasarkan penelitian diatas tingkat akurasi yang dimiliki sebesar $83 \%$. Untuk penelitian selanjutnya disarankan menggunakan keriteria yang tambahkan dan menggunakan metode klasifikasi yang lain untuk mendapatkan tingkat akurasi yang lebih tinggi.

\section{DAFTAR PUSTAKA}

[1] Fince Tinus Waruwu. Implementasi Algoritma Apriori Pada Analisa Pola Data Penyakit Manusia Yang Disebabkan Oleh Rokok. KOMIK (Konferensi Nasional Teknologi Informasi dan Komputer). ISSN 2597-4645 (media online) Volume I, Nomor 1, 2017.

[2] Harris Kurniawan. Analisa Pola Data Penyakit Rumah Sakit Dengan Menerapkan Metode Association Rule Menggunakan Algoritma Apriori. Seminar Nasional Informatik. 2014.

[3] Sofyan Yanuardy Saputra. Sistem Pendukung Keputusan Pemilihan Makanan. Prosiding Seminar Ilmiah Nasional Teknologi Komputer 
(SENATKOM 2015). ISSN : 2460 - 4690 Vol. 1. 2015.

[4] Gideon Abram Filando Suwarso. Sistem Pakar untuk Penyakit Anak Menggunakan Metode Forward Chaining. Jurnal INFRA. Vol 3. 2015.

[5] Prasetyono, Makanan Sehat. Info Makanan Sehat. 2009.

[6] Rusilanti, M.Si., DR., Menu Sehat untuk Pengidap Diabetes Mellitus. Jakarta: PT Kawan Pustaka. 2008.

[7] Giarratano, J. C. dan Riley, G. D. Expert Systems Principles and Programming Fourth Edition. Boston, Massachusetts: Thomson Course Technology.2005.

[8] Eko Prasetyo. Data Mining Konsep dan Aplikasi Menggunakan Matlab, Yogyakarta, Penerbit Andi. 2012.

[9] Han, J. and Kamber, M, Data Mining Concepts and Techniques Second Edition. Morgan Kauffman, San Francisco.ms and Intelligent System. 2006.

[10] Kusrini dan Luthfi, E. T., Algoritma Data Mining. Yogyakarta : Penerbit Andi. Penerbit Andi, Yogyakarta. 2009. 